I, G. (1974) 'A simplest turn taking in conversa-

aphy of Communication Semisovereign People

․ (2000) Intercultural roach. 2nd edn. Oxford:

ture and linguistic ideol Annual Meeting of the $-247$.

7derstand: Talk Between

ation and Endangerment

in. The role of the media Wodak (ed.), Language, lam: John Benjamins.

itical discourse analysis' 83.

course in Spain and Latin to Politics, Society, and १ Benjamins.

Society. Berkeley, CA

ones filosóficas. Tr. A ıes. México: Instituto de versidad Autónoma de

Power and ldeology.

If Discourse. London:

takt, ethnische Identität akte der Assimilation der rone mexikanischeKultur.

\title{
Globalization Theory and Migration
}

\author{
Stef Slembrouck
}

\subsection{INTRODUCTION}

This chapter engages with theories of globalization and migration through the lens of sociolinguistic inquiry. Globalization processes tend to be commonly talked about, sometimes celebrated and often contested, in terms of accelerated geographical reorderings in the fields of economic production, in money flows and technological spread. This chapter, however, asserts the centrality of language and symbolic practices and it does so by attending to one salient aspect of contemporary globalization processes, namely migration, while discussing implications for sociolinguistics. Two further introductory points deserve mention and help set the scope of discussion. Contemporary forms of migration are nowadays understood as a dimension of globalization processes, but it is worth reminding ourselves that the study of migration is in fact a much older theme, both in social and economic studies and in sociolinguistic enquiry. In more than one respect, the theme of migration predates the present burgeoning of empirical and theoretical interest in boundarycrossing processes, which are looked at through the lens of globalization phenomena (c.g. Thomas and Znaniecki, 1918, a pioneering work in the biographic approach to the sociology of migration). My second point therefore entails an historical horizon: to connect the present concern with, for instance, heightened multilingualism, which has resulted from an unrivalled increase in contemporary human movement around the world, with earlier historical linguistic and sociolin guistic understandings of migration-connected language developments which concentrated on the genesis of historically-recognized languages, language families and functional varieties, often in a context of imperialist expansion and colonial settlement.

\subsection{GLOBALIZATION AND THE LINGUISTIC CULTURAL TURN IN LATE MODERNITY}

To talk and write about 'globalization' as a process of accelerated transformation of local and regional phenomena into 'global' ones raises both the question of its 'naturalized' upper limit (phenomena that would truly cover the globe in its entirety) and its lower threshold (the extent to which phenomena can no longer be exclusively understood in 'local' terms or - perhaps more prominently escape the category and unit of the 'nation-state', which for quite some time has dominated the way in which sociopolitical and economic spaces have been inventorized, measured and regulated). The latter originated in the long-held assumption that societies would be coterminous with nation-states. Discussions about the upper limit of globalization are mostly invested with an idealized perspective. This is evident from the opposing teleologies of either a completely deregulated world economy or one driven by worldwide solidarity. Therefore, the stricter answer to the question (when it is posed from the 'global' end) is probably that we do not (as yet) inhabit a globalized world and it remains to be seen whether we ever will. As far as the 
lower threshold is concerned, one can conversely state the progressive evaporation of a sense of self-sufficient bounded locality (and, with it, the unit of the nation-state) in a range of transnational processes. One must add immediately here that what marks the present era as one of globalization is more a matter of degree, intensity and acceleration in social geographic complexity than that it would be possible to clearly identify an earlier era as pre-globalization (cf. Robertson's 1990 use of the term 'glocalization' to stress the tailoring effects of local conditions which interact with global flows). Globalization has been advocated as progress and advancement; it has also been denounced for its distuptive, de-authenticating and hegemonic effects. Boundary-crossing contact is probably as old as organized humanity itself, but this does not detract from the fact that the positing of the 'transnational' of course presumes the existence of geopolitical units that can be understood as nation-states, in itself a construction of modernity. Moreover, understandings of contemporary geographical orderings in terms of a dynamics of neatly-nested spatial units prove insufficient, as the nation-state has by now been widely observed as being bypassed from two ends. This is captured in Lash and Urry's (1994: 279) two-sided formulation that "contemporary nation states are now too small for the big problems of contemporary social life and too big for the small problems'. See also Swyngedouw (1996), and Persson and Stråth (2007), on the hollowing out of the functions of the nation-state by supranational and subnational forms of organization that compete with it, in the case of Swyngedouw (1996) with particular reference to economic collapse and industrial conflict within the European Union (EU). Bypassing the state cannot however be equated with its erasure. Especially when one turns to migration, it must be observed how the state and its typical sectoral divisions into fields (e.g. health, education, law, politics, etc.) continue to function as major channels for official policy, research funding, and publically-regulated responses to migration.

Different but related understandings of globalization phenomena have prioritized: (i) the agentive role of people in transnational 'networks of exchange'; (ii) the spread of goods, services and social categories such as labour, money, etc., via exchange relationships which are often captured conceptually as 'flows' (Appadurai, 1996); as well as (iii) resultant geographical demarcations of scope, distribution, circulation and uptake which are posited through the concept of '-scapes' (Appadurai 1990) - a metaphorical use which originates in the term landscape. Appadurai distinguishes five different types of 'scapes', depending on the content that has a particular distribution (ethnoscapes, financescapes, technoscapes, mediascapes and ideoscapes; the category of ideoscapes particularly includes the international spread of an European-American master namative of capitalist democracy around which political cultures are organized). Appadurai also notes multi-centredness and increasing disjunction between the 'scapes' of different spheres. The underlying emphasis is on constructedness, including how a 'scape' is always invested with viewpoint, and the bigger challenge here is indeed one of sustained cartographic effort. Thus, as a first example: throughout the 1990s, the US-Swedishowned television station VT4 was cable-transmitted throughout Flanders and broadcast in Dutch only (using subtitles for imported material); its television studios were situated near Brussels; yet, as the television station's corporate seat was registered in Britain and the station was answerable to British courts of law, it succeeded in circumventing Flemish restrictions on the broadcasting of commercials during children's programmes that would 'normally' apply to it (compare with Triandafyllidou et al., 2009 on the European media space).

In facing the challenges posed by globalization, historians, geographers and linguists, etc., have mostly (some would argue: inevitably) embraced a cultural turn, as it is difficult to separate our specific understandings of the contemporary era of globalization from other significant sociocultural shifts which originate in the latter half of the twentieth century: e.g. post-Fordist information economy (Bryson et al., 2000), risk society (Beck, 1992), reflexive late modern subjectivity (Giddens, 1991), etc., to name just three of these. Thus, accounts of deterritorialized finance and economy remain partial unless one also engages with the ways in which these are premised on particular culturalized communicative practices, as indeed is captured in the title of Lash and Urry (1994), Economies of Signs and Space. Similarly, a discussion of 'risk society' (in short: modern society is driven by its responses to particular types of risk which are intrinsic to modernization itself) will be at the heart of any analysis of durable economic, climatological and ecological development. Compare also with Giddens (2006) who anchors a proposed redefinition of the European 'social model' of the welfare state in the recognition of key shifts in sociocultural values.

Not surprisingly then, globalization has also been understood in more processual terms. For instance, 'space/time-compression' (Harvey, 1990 ) is a term used to describe the condition of (near-) simultaneity despite physical distance. It refers to the diminished importance of distance during a given historical moment - both the shortening of time and the shrinking of space.
The analytica include the $\mathrm{m}$ : ties that follov related conce tion' (Gidden! interlacing of local contextl ingly stretch Giddens, soci time. The prot denotes a hist societies and globalization opportunity $f_{i}$ space/time-dis sponding incr challenges ( $\mathrm{s} t$ Urry, 1994: 2 Fairclough (2 tanciation bri mediated mea

Finally, glc in terms of de The categorie periphery' as । (Wallerstein, cepts of cult tance. Inequa noted in relati intracontinent smaller-scale between urbs example, the quoting Lash spaces, bein, and heavily-n the highly 'wi munities' whi cosmopolitan immediately relations are $\mathrm{t}$ which involv instance of tl 1960s which Anatolian po urban periph Rotterdam, e scale of parti with Thirdemployed in and are occas interpreters patients who and Slembrol (2001: 368) nomic global sociolinguisti spatially hom and contribut 
The analytical imperatives that follow from it include the manifold complexities and incongruiinclude the manifold complext co-temporalities. A related concept is that of 'space/time-distanciation' (Giddens, 1984, 1990), which refers to the tion' (Gidens, social relations at a distance with int increasingly stretched across greater distances. For Giddens, social life is ordered across space and time. The problematic of 'space/time-distanciation' denotes a historical trajectory in the evolution of societies and it is central to understanding both globalization and late modernity: the increase in opportunity for human control that comes with space/time-distanciation is matched by a corresponding increase in the relevance of larger-scale challenges (see: Callinicos, 1985; and Lash and Urry, 1994: 230ff. for a critical assessment). As Fairclough (2006: 94ff.) stresses, space-time distanciation brings out the intimate ties between mediated meaning-making and power.

Finally, globalization has also been understood in terms of determinate relationships of inequality. The categories of 'core', 'periphery' and 'semiperiphery' as developed in world-systems analysis (Wallerstein, 2004) here appear as yardstick concepts of cultural-geographic proximity and distance. Inequality through dependency has been noted in relations of a global scope (e.g. inter- and intracontinental North/South-relations, or within smaller-scale units, e.g. a sharpened contrast between urban and rural spaces). In the latter example, the set of contrasts has entailed (again quoting Lash and Urry, 1994: 28) that the urban spaces, being information-soaked, service-rich and heavily-networked, come closer to inhabiting the highly 'wired villages of non-contiguous communities" which by one definition would be called cosmopolitan and globalized. One must also immediately add here the ways in which such relations are being replayed in dislocated contrasts which involve diaspora and migration. Think for instance of the state-organized migration of the 1960 s which resulted in large sections of a rural Anatolian population in Turkey ending up in the urban periphery of cities such as Essen, Ghent, Rotterdam, etc.; or consider an example at the scale of particular institutions, e.g. how doctors with Third-World degrees find themselves employed in the pharmacy of a Brussels hospital and are occasionally called into the wards to act as interpreters during medical encounters with patients who share their first language (Collins and Slembrouck, 2009: 35-6). Coe and Yeung's (2001: 368) observations in the context of economic globalization can be extended to attendant sociolinguistic processes: globalization is not spatially homogenizing, but instead depends upon, and contributes to uneven geographic development at different scales'. The same is true of increases in space-time distanciation. However, at the same ime, the constructedness of these processes, including their potentially being encouraged, embraced, appropriated or resisted, does not come with an immutable inevitability, as globalization with an immutable inevitex and conflicting tendencies, the outcomes of which cannot be predicted a priori'.

Central to sociolinguistic enquiry here are questions of the (often simultaneous but divergent) representations of (trans-) locality, as spatialized and as inserted in time, and as struggled-over realities of person, place, group, object, etc. This has been the subject of much sociological enquiry, e.g. Fenton and Bradley's (2002) study of the role of economic action in the articulation of co-occurring ethnic identities, while sociolinguistic research has focused on representations of both élite and ordinary actors, representations distributed along mass media and high-tech channels or expressed in the secluded space of face-to-face encounters (e.g. Baynham and De Fina (2005) on experiential narratives of displacement and relocation; Delanty et al. (2008) on the cultural resources, framing devices and repertoires of justification articulated in racial exclusion; CaldasCoulthard and Iedema's (2008) on the effects of failure and uncertainty in people's constructions of identity when they face change in diverse border-crossing contexts, including migration and asylum). The study of such representations and their circulation dynamics is however best not divorced from an analysis of sociolinguistic resources, understood in the widest sense possible: languages, registers, discourse formats, interactional set-ups, etc., which, in their own right, are often subject to (trans)local processes of recontextualization - appropriation, shift and transformation. In this, purchase in mobility and articulation at a higher scale are often at stake (cf. Haarstad and Fløysand, 2007 on 'scale'jumping' and empowerment). Here are two fairly rudimentary examples of 'national' articulation which attend to their reception at a higher scale and the role which sociolinguistic choices play in these: the ANC's (African National Congress) choice for an anglophone articulation of the category Black (rather than 'non-racial' or 'non-white', see Howarth, 2000: 106) was both a unifying factor in South Africa's struggle against apartheid and a tactical choice which facilitated uptake in news media around the world and in world political forums such as the UN. This can be contrasted in the post-apartheid era with, for instance, the reconciliatory philosophy of Ubuntu (a mobilizing category borrowed from Nguni) which, since 1994, has been frequently invoked as a specifically pan-African and racially-inclusive approach

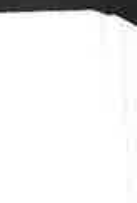


to defining one's humanity through that of others (cf. in Zulu, 'Umuntu Ngumuntu Ngabantu' means that 'a person is a person through other persons'). As Haarstad and Fløysand (2007: 289) point out, 'it it is necessary to probe deeper into the power relationships that are produced by the restructuring of relationships in time and space'. Let me now turn to migration.

\subsection{MIGRATION, COLONIALISM AND THE FORMATION OF LINGUISTIC RESOURCES}

Migration, then, specifically brings out the aspect of human movement. It is an old theme - traditionally discussed in relation to tribally-organized collectivities (e.g. Germanic migration within Europe in the first centuries; large-scale Bantu migration across Southern Africa from the fourteenth century onwards), or in terms of colonial settlement which accompanied trade missions and military campaigns (e.g. Roman settlement across Europe or successive waves of European settlement in North America). The impact of such migrations on the formation of 'languages' as durable effects of sustained language contact is one theme within historical linguistics, e.g. substratal effects (Bynon, 1997: 252ff.) of local Germanic vernaculars on the language use of the Roman colonizers which underpin the transition from Latin to French (see also: Lass, 1997; Campbell, 1998). It has also been a theme within sociolinguistics: pidginization and creolization are typically associated with the colonization of the New World by European-based powers (Thomason and Kaufman, 1998 is a key reference in this area). Specific concepts and terminology thus reflect an interest in specific periods in history, though research, even where change has been presented as 'contact-induced' (Kaufman, 2003), has not necessarily been couched in an analysis of lived experiences of migration, while the distinction between 'creoles' and 'languages' has been challenged both on theoretical and empirical grounds (e.g. Ansaldo and Matthews, 2001).

What marks the current era of globalization as different is, first of all, the unprecedented surge in human movement around the globe (refugees, displaced persons, migrants), mostly in the form of selective or collective responses to economic deprivation, war and conflict, political prosecution and genocide. This is the migration of the havenots' in search of a better or safer life elsewhere, often, though not exclusively, moving from relative '(semi)-periphery' to the 'core'. Note that what counts as 'centre' and 'margin' will be highly circumstantial and invites sophisticated and layered readings of 'difference'. Secondly, there are the increasing flows around the world of a whole range of 'haves' who, in various functional modalities, spend time away from base localities because they can afford to do so, either travelling as tourists or as members of specific professional, occupational and retirement communities. Students can be found in both categories. The theme of migration invites inquiries into the positioning of groups in transformed labour relations (e.g. Lamont, 2000) and a second important area of attention is of course that of minority rights, especially in relation to the institutional domains of the welfare state (e.g. Kymlicka, 1995, 2001). Experiences of migration are often continual or recursive processes (more than just one-way experiences), and may involve continued contact with, even physical movement between, contexts of ancestry and current residence (Basch et al., 1994; Sassen, 1999; e.g. Galasin'ski and Galasin'ska, 2007 and Galasin'ska and Koslowska, 2009 for sociolinguistic enquiries into how immigrants makes sense of evolving 'parallel' worlds; e.g. Budach, 2009 for how this may be tied up with the transnational exchange of commodities; e.g. Valentine et al., 2009 for the effects of subsequent moves in a migration trajectory on functional distribution within specific sociolinguistic repertoires).

Typically, effects on the language use of individuals (as part of collectivities) is, in this area of inquiry, talked about in terms of 'linguistic fate', one of language maintenance - e.g. through heritage language programmes, language adaptation, shift, death or loss, patterns of code selection, code-switching and style shifting as discernible processes of (emergent) language change in successive generations who are born in/outside the host country (Saville-Troike, 2003: 201ff.; see McConnell, 1997: 353ff on the structural variables of 'status', 'demography' and 'institutional support' which affect ethnolinguistic vitality). Three comments must be added here immediately:

1 The theme of language maintenance/loss brings together postcolonial contexts (in which the hegemony of the colonizer's language is asserted) with contexts of migration (in which the migrant community's language encounters a local language which is established throughout the social spheres). Language dominance is probably a common factor. Note that some national contexts have both, e.g. the USA or New Zealand.

2 Language contact must also be put in the context of 'return'. 'Return' here can mean 'in person' when returning for a shorter or longer period of time (e.g. Zentella, 2003). This may come with a focus on 'second languages' (e.g. Taura, 2008 on the retention/loss of English by returnees in a Japanese context). Return is also to be interpreted 's] language lear assert the pre ancestry (e.g. for whom Fre the regulation Kirkpatrick (2 expectations newsreaders $\mathrm{i}$

3 In addition, s edentedly res social indexic aspects of val ous forms of tions, crossinc accents (e.g.

However, we resources of in being used in ac to the level of $l_{i}$ pronouncements which linguistic a further discus what else is ne complexities of contemporary interest in glol the previous si language and been modelled on the wide various niches enquiry and the niches can mak migration.

\subsection{AN ON- OF MIG SOCIOL}

Globalization pushed socioli some of the re pline, as it has guistics withou themes of, jus translation stuc tion, analysis discourses, an also applies co

Globalizatic migration have in translation a to a point wher or, more gen have to shrug 
interpreted 'symbolically', often in processes of language learning and use which continue to assert the prestige of a collective language of ancestry (e.g. Heller (2003) on Franco-Ontarians for whom French-French plays a major role in the regulation of access to international jobs and Kirkpatrick (2007: 106ff.) who notes continued expectations of British RP for contemporary newsreaders in South Africa).

3 In addition, studies of migration have unprecedentedly resulted in the thematization of the social indexicalities and language ideological aspects of valuations which cluster around various forms of code-switching, mixings, stylizations, crossings, lingua franca uses and ethnicized accents (e.g. Rampton, 1995; Auer, 2007).

However, we still need to ask how the linguistic resources of individuals, resources we can see being used in actual interaction, can, be projected to the level of language communities, in view of pronouncements about the long-term directions in which linguistic resources develop (see below for further discussion). In addition, we must ask what is needed to come to terms with the what else is needed to comactice in contexts of complexities of language practice inst contemporary migration. Set against the wided in interest in globalization processes outlin between the previous section, the relations some respects, language and migration has, in some respecially been modelled further by drawing beneloped in on the wide range of interests developed in various niches of linguistic and sociolinguistic enquiry and the specific contributions which these niche studies of globalization and migration.

\subsection{AN ON-THE-GROUND ANALYSIS OF MIGRANT-RELATED SOCIOLINGUISTIC DIVERSITY}

Globalization and contemporary migration have pushed sociolinguistic researchers to question some the received boundaries of their discipline, guistics without taking on board some of the key themes of, just to name four 'disciplines' here: translation studies, language learning and education, analysis of institutional and professional tion, analysis and literacy studies. The challenge discourses, and literacy
also applies conversely.

Globalization and contemporary forms of migration have resulted in an exponential growth in translation and interpreting (Cronin, 2003) - up where analyses of medical consultations to a point where analyses ocial welfare encounters or, more generalfy, boundedness of received monolingual contours. In recent years, one has witnessed a number of reorientations in education and language pedagogical fich invite a sociolinguistic turn sensitive frilingualism, emergent language varieties, and the comolinguistic attitudes. language ideologies and socion departments have For instance, national ed a had to rethink their 'national learning of official lum', so as to include also the learning of experilanguages as a second language (a nuropean states). ence in quite a few Western Europe specific Research in this area has also nome contexts, challenges of curricular design. this has meant facing highly diverifom successive $\mathrm{X}$ as a second language resulting from successive waves of immigration: e.g. newcons with prejust arrived with no $X$ at all vs users with $\mathrm{X}$ school neighbourhood experience ine time, chat as a second language. At the same tim osed by lenges of teacher recruitment haves in the immithe organization of language course taught in the grant languages when the diaspora (Creese et al., 2008). These may well be not new in their own right, but thected by recent unprecedented in contexts to address them may waves of migration; the need to address and increased also have come with greater complexity (e.g. hyperdivers simultaneously at ferent language background a situation in which play, or the complexities of a situation in wived the language learning needs of through an estabimmigrants are being addressed curriculum for lished second language learilarly, professional indigenous minorities). Simies were previously and institutional discourse stadiain, in which attenvery much a monolingual terrain, in whes mostly tion to diversity in linguistic resources' vs 'expert restricted to matters of lay speak speak' with some attention paid experience and orientations in the coding now become a degrees of client education. It hecifics of multiterrain which ventures into the specifics of mofeslingual institutional encounters in mediated through sional-client communication is mretation, codeinformal or professional interingua franca with switching, or by resorting to a lingua franca wht to varying levels of functional proticmbrouck, 2006; the encounter (e.g. Collins and Moyer (forthcomGotti and Salager-Meyer, 2006; e.g. Benmaman, ing) on medical interaction, 2003 on legal 2000; Haviland, 2003 and Trinch, 2003 on levelopments, quescontexts). Following these deved, too - not only tions of literacy have been posed, tod in a context the more traditional questions raised in a conts where professionals and institutional agents written clients who thus far have notficulties in managlanguage or who experience dificultie of IT-driven ing it but also literacy in the use of rT-driven 
technologies of communication, next to cross-national experiences in institutional literacy, literacy related to expert-systems as presupposed by the late modern ideal of self-governance, and literacy in response to institutional shifts in value which favour client-centredness, choice and the negotiation of institutional courses of action (see chapter by Barton and Lee in this volume). The paradigmatic shift towards 'New Literacy Studies' (e.g. Street, 1993; Collins and Blot, 2003) not only accords with these programmatic requirements but also is much necessitated by the complexities of the migrant experience. One specific theme that has often been noted in this area concerns the interactional deficits of decontextualized written solutions for the communicative gaps induced by language difference. That this is an area at the interstices of analysing institutional regimes of client-oriented communication and multilingual encounters underlines the importance stated earlier of studying the language impact of migration in relation to contemporary value orientations in institutional cultures.

In a more general vein, Coupland states (2003: 466) that 'the qualities of linguistically mediated social experience that define "local" ... all potentially carry an imprint from shifting global structures and relationships'. Echoing Comaroff and Comaroff (1992: 32ff.), macro processes always 'have their feet on the ground'. There is a need for a sociolinguistic perspective which invites equal attention to representations of difference and the situated actions of individuals, both in the microinteractional spaces in which difference and diversity are acted out and in the mediated spaces of mass communication. In practice, it is not possible to maintain a strict distinction between the two types of context. The difference is one of scale of inquiry, not one of priority. In fact, studies of mass media representations of globalization and migration are invited to pursue also the question of how situated individuals interactionally engage with such representations (adopting an actional perspective, alongside the more commonly adopted perspective of textual constitution which is characteristic of much in media studies). Conversely, studies which prioritize the micro-sequential dynamics of face-to-face interaction are equally invited to address the larger-scale structuration effects brought about by mass media representations, as they permeate local sense-making in face-to-face interaction. Thus, representations in (inter)national media will tend to 'dawn upon' the neighbourhood experiences of migration which they cover, while neighbourhood experiences through national exposure impact upon the construction of relevant socioeconomic realities in areas unaffected by migration flows. Expressed boldly: the notion of the global itself is best approached as articulated across interacting levels of social geographic reality. Burawoy (2001:148) adds the meta-reflection that the pulses of academic endeavour are equally implicated: inasmuch as for him the global invites ethnographic understanding, ethnography has gone global, too (anthropology in particular had for a long time already depended on a fundamental perception of border-crossing colonial relationships, whereas sociology mostly took for granted the nation-state as its natural unit of analysis).

Recent work in political, cultural and economic geography has thematized the problematic of interacting levels of analysis through the notion of 'scale' itself (see above) -, the construction of spatial and temporal units and coordinates in socioeconomic processes and, as sociolinguists will add, their articulation 'in' discourse. Scale is a very old concept in geography: in fact, it is hard to think about geographical units of analysis unless one deploys a concept of 'scale'. More recent work emphasizes how scale is socially produced. In the words of Haarstad and Fløysand (2007: 292):

... the 'scale question' has been addressed in recognition of the increasing interconnectivity of social relations caused by time-space compression, which necessarily problematizes the spatial parameters of those relations and the geographical context in which they occur .... Globalization does not merely detach social relations from space (deterritorializing), but also reinscribes these relations in new ways (reterritorializing).

Attention to 'scale' and processes of 'scaling' ('upscaling', 'downscaling', 'rescaling', etc.) allows us to circumvent some of the circularity that comes with received micro/macro-reasoning: communicative events are often best viewed as 'micro', 'meso' and 'macro' at the same time and much will depend here on whose interpreta tive viewpoint is given priority in analysis. Thus, the child's limited Dutch displayed in a language immersion classroom in Ghent may, at one and the same time, represent (for the teacher) a recentlyarrived child who is coming to terms with a challenging new environment and who copes reasonably well given that the parents do not speak the language either, and (for the visiting school inspector) yet another instance of a failing national policy of language integration for immigrants. The construction of contextual categories is subject to the indexicalities which are presupposed, played out or interactionally worked up at the moment of speaking (and, retroactively, when interpreting discourse, as an aspect of recontextualization). Indexicalities can be viewed as 'ordered' (Silverstein, 2003). The use of 'scale' and 'scaling' can thus l cern with dis/re-loc situatione and inter: new cont followin the relate Gal, 200 Dublin b during a mated ho Irish pul different This, he and the $\mathrm{t}$ (i) 'Irelas friends; ( from $\mathrm{Dr}$ 'guys frc when ha who gre recursivs distinctir group ol the large

Note, up beyo] here is. heritage tary sch. are volu tic, relic

Youne ated ways mater ers an ought endor natior accep peopl multil respo tiated throu by otl

What is spatiali suppos two tin adolesc archica itage $\varepsilon$ institut valued 
can thus be extended to address a theoretical concern with the effects of de/re-territorialization and dis/re-location on the construal of place, time and situational reference as they are interpretatively and interactionally 'pinned down' or exported to a new context of expression (Baynham, 2009). The following vignette is anecdotal but illustrates well the related point of 'fractal recursivity' (Irvine and Gal, 2000). A former colleague, who grew up in Dublin but has lived in Belgium for over 20 years, during a discussion of the concept of 'scale' intimated how, when frequenting one and the same Irish pub in the centre of town, he embodied different units of reference for his interlocutors. This, he said, bore both on the topics attended to and the evaluative meanings exchanged on these: (i) 'Ireland', when he visited the pub with Flemish friends; (ii) 'Flanders', when meeting with visitors from Dublin or the Irish Republic; and (iii) the 'guys from the other side we never got to talk to', when having a drink with a colleague from the UK who grew up in Ulster. Distinctions are applied recursively to a fraction of a unit, as meaningful distinctions ate played out to constitute a smaller group or individual with presupposed ancestry in the larger-scale unit.

Note, in addition, that the interest in scale takes up beyond this. As a further illustration, therefore, here is what Creese et al. (2008: 18) state about heritage language classes in the UK complementary schools they studied (complementary schools are voluntary schools which serve specific linguistic, religious or cultural communities):

Young people in complementary schools negotiated paths for themselves which were in some ways contrary to the ideologies of the teaching materials used in complementary schools. If teachers and administrators held the view that students ought to learn a community language as an endowment of knowledge of a national history, nationalism, and identity, this was not necessarily accepted unproblematically. Rather, the young people's attitudes to their languages, and their multilingual practices, constituted an urbane response to their place in the world, as they negotiated subject positions which took them on a path through language ideological worlds constructed by others.

What is noteworthy about this instance is that the spatialization of the young learners which is presupposed in the learning materials intersects with two timescales: that of heritage and that of urban adolescence. The latter contrast is organized hierarchically in internally-conflicting directions: heritage as valuable tradition which is supported institutionally and urban adolescence as lived time valued by the adolescents. The net result is a social dynamics which is undecided and in flux (Creese et al., 2008: 18):

Young people found ways to parody the texts, their teachers and themselves, often questioning and sometimes ridiculing the folk stories, traditional rituals, ceremonies and festivals. At other times, young people showed a willingness and interest in the 'heritage' chosen by their teachers to focus on in class and assemblies and showed much enthusiasm in participating in community events such as Diwali festivities (Gujurati case study) and Children's Day (Turkish case study).

The further point illustrated is that of certain 'sites of engagement' (Scollon, 1997) over others being particularly amenable to articulations of scale and even scale-shifting.

One of the specific challenges posed to scalar analysis resides in the multiple uses of the term 'scale'. One can detect at least four uses:

1 Scale as a category rooted in experience and participant perception - refers to particular practices attended to by participants as reflecting and bearing upon particular time/space-scales?

2 Scale as a value-oriented gauge in the assessment of structured relationships - scale analysable as determinate relationships of inequality; as Fairclough (2006) stresses, this need not be transparent to those immediately involved.

3 Related to this, 'scaling' refers to a dynamic process which connects situated phenomena with trans-situational power, purchase and mobility (or the lack of these).

4 Finally, there is scale in the way it is more traditionally understood by geographers, as by and large a matter of drawing on a set of decontextualized units of analysis and inventory (calendar and clock time and units of square measurement, together with received geopolitical and institutional-organizational units).

One response to the challenges noted is that of multiple, interconnected readings and of adequacy in interpretation. The problem of interpretation is confounded by the inevitable dilemmas posed by Fairclough (2006: 5) when he draws attention to the paradox that, in practice, it is not possible to draw a strict separation between, on the one hand, discourses about globalization (which are often contested) and, on the other hand, globalization as real processes which are not necessarily recognized by participants for what they are. The paradox is that processes can only be talked about by resorting to representations. The resultant programme is threefold: it is one of developing an analytical-interpretative vocabulary which adequately captures process, does justice to experience and 
has purchase in the formulation of equitable policy and feasible intervention. In addition, what appears to be needed is not only that we dynamically conceive of a large-scale process in direct relation to detailed analysis of local symbolic processes but also that we capture the scalar complexities and contradictions that accompany the many different aspects of globalization. This way we may also succeed in capturing the unpredictable, push-pull effects of globalization which are easily missed in the sweeping manifestos. This calls for an ethnographic turn, much in the spirit of Burawoy (1991) and Gal and Kligman (2000) for whom ethnography counts as a specific engagement with 'thick' empirical detail which is oriented to the advancement of realistic socialtheoretically-informed understandings.

\subsection{CHALLENGES POSED TO RECEIVED SOCIOLINGUISTIC NOTIONS AND THEORIZING}

The challenges posed by a sociolinguistics of globalization and migration invite multiple connections with long-standing sociolinguistic themes such as studying the effects of language contact. While stressing the continuities, there is also a need to think through the discontinuities which have been foregrounded in recent research. The shift from a sociolinguistics of 'community' to one of 'contact' is one of these (Clyne and Kipp, 2006; Collins et al., 2009; Rampton, 2009). Some definitions of speech communities have stressed commonality of language - the monolingual paradigm (e.g. Lyons, 1970) - while other definitions go by regularity of interaction (e.g. Gumperz, 1962), in this way allowing bi/multilingual speech communities. The impact of migration reaches further than the latter, as rather fundamental questions are raised about 'contexts' of interpretation, especially the temporal/spatial dimensions of language use and meaning-making (the shift towards a paradigm of spatialization and its central category of 'scale' discussed above bears testimony to this). Not surprisingly, this comes with conceptual challenges which extend to the category of 'language' itself (e.g. Blackledge and Creese, 2008). Migration has posed challenges of hybridity and the occurrence of selectively emergent varieties with limited distribution as socially identifiable registers (e.g. the adolescents of Maghreb descent in Jaspers' (2005) fieldwork who socially identify and regularly deploy stylizations of 'newcomer Flemish' and 'Turkish Flemish'). Similarly, the theme of world languages, recast more recently into a debate about linguistic imperialism and imposition 'from above' (Mazrui, 1975; Phillipson, 1992; Canagarajah, 2002; Holliday, 2005), has been addressed as one of local and global dominance through global circulation (e.g. standard English as a colonial inheritance; standard English and its purchase in a transnational job market). At the same time, various kinds of hybridization have been described as coming 'from below' (e.g. Alim et al., 2008 on hiphop registers; e.g. English learned and developed en route as a medium for articulating refugee experiences). With this, questions of coexistence and competition with local languages have been raised for both postcolonial and diaspora contexts (e.g. Vigouroux and Mufwene, 2008). Note that competitive coexistence is also a major aspect of language policy in supranational spaces such as the EU or globalized markets for mobile phones and software (Krzyźanowski and Wodak, 2007 on the hegemonic multilingualism of a number of 'core' working languages in the EU; e.g. Cronin, 2003 and House, 2008 on the implications of a growing distributional dynamics of 'covert translation': the need for fast global dissemination has resulted in simultaneous and automated access to a dominant anglophone source text and its translations for recipients in many different linguistic and cultural contexts.) In addition, questions such as, 'What is English?', in fact an old theme in the sociolinguistics literature, have returned, now with more stress on the face-to-face contact between non-native Englishes. For instance, Maryns (2005) gauges the impact of different 'Englishes' as a dimension of the interactional and interpretative asymmetries which bear on the contact between bureaucrat and asylum seeker in which, say, a variety of English which builds on Krio from Sierra Leona meets 'face-to-face' with the 'outer circle' secondaryschool English of the Flemish institutional representative. The outcome of the contact is deeply consequential for the applicant. Attempts at formulating workable (de-ethnicized and translocal) criteria for 'international English' or 'English as a lingua franca' have given rise to intense debate. (Key tenets of this debate are captured in, for example, Rubdy and Saraceni, 2006.)

Less often dwelled upon are the challenges posed to the concept of 'genre'. Genres are traditionally thought of as contained by a societally-defined community of practice or a language community. Thus, the next step from locating discursive formats which are relatively more/less mobile across situational contexts (e.g. the indepth interview as a trans-situational discursive format) is to talk about genres which are better understood as ordered in transnational spaces of circulation (through processes of borrowing, appropriation, imposition and translation). Genres posses: genres connec wherea (e.g. hi across suscep1 alizatic mine 0 is mos particu on the the use artefac' 'genre' e.g. Sle In ar ing log defined sized d bourho toinfor to mig. with th to be $\mathrm{c}$ ristic $\mathrm{r}$ Also, i] in whic too eas across of text This h: produc (Hanks has ad audienı artefac provid langua: tailore Richarı text? observ variant probleı institut characl to engi snation take pi within Marcu: raphy stifling 
possess or lack transnational mobility. Certain genres can be thought of as almost ontogenetically connected to global landscapes (e.g. email), whereas other genres just appear to travel very fast (e.g. hip-hop). Questions of relative homogeneity across transnational landscapes and/or relative susceptibility to local adaptation and recontextualization are very much at the forefront and undermine often-held assumptions that generic variation is mostly to be situated inside the space of a particular language or a community. (See research on the adoption of television formats worldwide: the use of a single language in the broadcasted artefact is often a mistaken indicator that the 'genre' would belong to the "language community'; e.g. Slembrouck, 1998.)

In addition, it is also worth noting how a prevailing logic of homogeneous language communities defined by language, ethnicity and nationality (now sized down to the scale of cities, regions, neighbourhoods) in more than one respect has continued to inform both institutional-organizational responses to migration in education, health, etc., and along with this, many research initiatives. Research tends to be organized ethnolinguistically, often for heuristic reasons of uniformity of sample and focus. Also, in this area we face challenges to a paradigm in which 'the systematicity of language' is perhaps too easily taken for granted (Rampton, 2009).

Other methodological challenges to a sociolinguistics of migration and globalization pertain to the logistical difficulties involved when concentrating sociolinguistic and ethnographic effort across transnationally-constituted constituencies of text interpretation and sites of engagement. This has been noted earlier for analyses of media products which are consumed simultaneously (Hanks, 1996: 140ff. on television). Globalization has added the further challenge of transnational audiences who consume one and the same video artefact on CNN or Eurosport, a channel which provides simultaneous commentary in different languages, with advertisements during the breaks tailored to different audience segments (cf. Richardson and Meinhof, 1999). Where is the text? And, what is the best vantage point for observing interpretive practice? In a different variant, a similar set of heuristic and logistical problems presents itself when one is analysing institutional contact in a neighbourhood which is characterized by hyperdiversity, or indeed if one is to engage with linguistic ethnographies of transnational mobility which invite the researcher to take part in a journey rather than do fieldwork within a single community space. (See also Marcus's 1998 advocacy for multi-locale ethnography which seeks to overcome some of the stifling effects of a straightforward micro-macro dichotomy; the advocacy is to be systemsdirected; ethnography can become more 'flows'sensitive by actively participating in the complex connections between places, rather than being single-place focused.)

The question of 'community' as a unit of analysis also surfaces in the need to revisit language/ class-analysis in contexts of migration especially how social class connects to particular language experiences in institutional contexts (see chapters by Mallinson and Dodsworth in this volume). Collins and La Santa (2006: 1) observe how we currently 'lack models which translate ethnicity and class, as social categories, into the processual and interactional concepts likely to generate insight into learning processes'. The concept of 'social class' has been much tied up with the sociology of the nation-state. It has tended to be absent from sociolinguistic efforts to come to terms with the sociolinguistics of the transnational, often replaced in this by 'ethnicity', 'culture' and 'ethno-national identity' as categories which would be more easily amenable to transnationally-defined populations.

Finally, the theme of the nation-state, although problematized, is far from absent in globalization and migration studies. The nation-state continues to be articulated in literature, film, discourses of government, popular events, etc. (e.g. Billig, 1995). Especially in the context of migration studies, there are various indications of a continued role for the nation-state as a significant regulating force in how sectors of society (e.g. politics, health, education, etc.) respond to waves of migration. This brings us full circle, returning to the oldest theme in sociolinguistics, that of society and language use. What might we mean then by 'society'?

\section{REFERENCES}

Alim, H., Ibrahim, A. and Pennycook, A. (2008) Global Linquistic Flows: Hip Hop Cultures, Youth Identities, and The Politics of Language. New York: Taylor and Francis.

Ansaldo, U. and Matthews, S. J. (2001) 'Typical creoles and simple languages. The case of Sinitic', Linguistic Typology, $5(2,3): 311-26$

Appadurai, A. (1990) 'Disjuncture and difference in the global culture economy', Theory, Culture and Society, 7(2), 295-310.

Appadurai, A. (1996) Modernity At Large: Cultural Dimensions of Globalization. Minneapolis, MN: University of Minnesota Press.

Auer, P. (ed.) (2007) Style and Social identities. Alternative Approaches to Linguistic Heterogeneity, Berlin: Mouton de Gruyter. 
Basch, L., Schiller, N. and Blanc, C. (1994) Nations Unbound: Transnational Projects, Postcolonial Predicaments, and Deterritorialized Nation-States. Langhorne, PA: Gordon and Breach.

Baynham, M. (2009) " "Just one day like today": scale and the analysis of space/time orientation in narratives of displacement', in J. Collins, S. Slembrouck, and M. Baynham (eds), Globalization and Languages in Contact: Scale, Migration, and Communicative Practices. London: Continuum. pp. 130-47.

Baynham, M. and De Fina, A. (2005) Dislocations/Relocations. Narratives of Displacement. Manchester: St Jerome.

Beck, U. (1992) Risk Society: Towards a New Modernity. New Delhi: Sage.

Benmaman, V. (2000) 'The Spanish speaker + interpreter services = equal access to the judicial system: Is the equation accurate?', in A. Roca (ed.), Research on Spanish in the United States: Linguistic issues and Challenges: Somerville, MA: Cascadilla Press. pp. 82-94.

Billig, M. (1995) Banal Nationalism. London: Routledge.

Blackledge, A. and Creese, A. (2008) 'Contesting 'language' as 'heritage': negotiation of identities in late modernity', Applied Linguistics, 29(4): 533-54.

Bryson, J., Daniels, P., Henry, N. and J. Pollard (2000) (eds) Knowledge, Space, Economy. London: Routledge.

Budach, G. (2009) "Canada meets France": recasting identities of Canadienness and Francité through global economic exchanges', in J. Collins, S. Slembrouck and M. Baynham (eds), Globalization and Languages in Contact: Scale, Migration, and Communicative Practices. London: Continuum. pp. 209-32.

Burawoy, M. (1991) Ethnography Unbound: Power and Resistance in the Modern Metropolis. Berkeley, CA: University of California Press.

Burawoy, M. (2001) 'Manufacturing the global', Ethnography, 2(2): 147-59

Bynon, T. (1997) Historical Linguistics. Cambridge: Cambridge University Press.

Caldas-Coulthard, C.-R. and ledema, R. (2008) Identity trouble Critical Discourse and Contested Identities. New York: Palgrave Macmillan.

Callinicos، A. (1985) 'Anthony Giddens. A contemporary critique', Theory and Society, 14(2): 133-66.

Campbell, L. (1998) Historical Linguistics. An Introduction Durham, NC: Duke University Press.

Canagarajah, S. (2002) A Geopolitics of Academic Writing Pittsburgh: University of Pittsburgh Press.

Clyne, M. and Kipp, S. (2006) Tiles in a Mulitilingual Mosaic: Macedonian, Somali and Filipino in Melbourne. Canberra: Pacific Linguistics.

Coe, N. M. and Yeung, H. W. C. (2001) 'Geographical perspectives on mapping globalization', Journal of Economic Geography, 1: 367-80.

Collins, J. and Blot, R. (2003) Literacy and Literacies: Texts, Power, and Identity. Cambridge: Cambridge University Press.

Collins, J. and La Santa, A. (2006) 'Analyzing class and ethnicity as communicative practices: a case study of migrationbased multilingualism in Upstate New York'. Working
Papers in Urban Language and Literacies, 40. London: King's College. Available at http://www.kcl.ac.uk/schools/ sspp/education//research/groups/lg/wpull.html.

Collins, J. and Slembrouck, 5. (2006) '"You don't know what they translate": language contact, institutional procedure and literacy practice in neighbourhood health clinics in urban Flanders', Journal of Linguistic Anthropology, 16(2): 249-68.

Collins, J. and Slembrouck, S. (2009) 'Goffman and globalisation: frame, footing and scale in migration-connected multilingualism', in J. Collins, S. Slembrouck, and M. Baynham (eds), Globalization and Languages in Contact. Scale, Migration, and Communicative Practices. London: Continuum. pp. 19-41.

Collins, J., Slembrouck, S. and Baynham, M. (eds) (2009) Globalization and Languages in Contact: Scale, Migration, and Communicative Practices. London: Continuum.

Comaroff, J. and Comaroff, J. (1992) Ethnography and the Historical Imagination. Boulder, CO: Westview.

Coupland, N. (2003) 'Introduction: sociolinguistics and globalisation', Journal of Sociolinguistics, 7(4): 465-72.

Creese, A., Baraç, T., Bhatt, A., et al. (2008). Multilingualism in Complementary Schools in Four Linquistic Communities. University of Birmingham.

Cronin, M. (2003) Translation and Globalization. London: Routledge.

Delanty, G., Wodak, R. and Jones, P. (eds) (2008) Identity, Belonging and Migration. Liverpool: Liverpool University Press.

Fairclough, N. (2006) Language and Globalization. London: Routledge.

Fenton, S. and Bradley, H. (eds) (2002) Ethnicity and Economy. Race and Class Revisited. New York: Palgrave Macmillan.

Gal, S. and Kligman, G. (2000) The Politics of Gender After Socialism: A Comparative-Historical Essay. Princeton: Princeton University Press.

Galasiński, D and Galasińska, A. (2007) 'Lost in Communism, lost in migration: narratives of the post-1989 Polish migrant experience', Journal of Multicultural Discourses, 2(1): 47-62.

Galasińska, A. and Koslowska, 0. (2009) "Either" and "Both" - the changing concept of living space among Polish post-communist migrants to the UK', in J. Collins, S. Slembrouck, and M. Baynham (eds), Globalization and Languages in Contact: Scale, Migration, and Communicative Practices. London: Continuum. pp.170-88.

Giddens, A. (1984) The Constitution of Society. Cambridge: Polity Press.

Giddens, A. (1990) The Consequences of Modernity. Cambridge: Polity Press.

Giddens, A. (1991) Modernity and Self-identity. Stanford, CA Stanford University Press.

Giddens, A. (2006) Europe in the Global Age. Cambridge: Polity Press.

Gotti, M. and Salager-Meyer, F. (2006) Advances in Medical Discourse Analysis: Oral and Written Contexts. Bern: Peter Lang.

$$
\begin{aligned}
& \text { Gumf } \\
& A n \\
& \text { Haars } \\
& \text { por } \\
& \text { mir } \\
& 28 \text { s } \\
& \text { Hanks. } \\
& \text { Oxf } \\
& \text { Harvey } \\
& \text { intc } \\
& \text { Havilar } \\
& \text { on } \\
& 105 \\
& \text { Heller, } \\
& \text { Etht }
\end{aligned}
$$


Gumperz, J. (1962) 'Types of linguistic community', Anthropological Linguistics, 4: 28-40.

Haarstad, H. and Floysand, A. (2007) 'Globalization and the power of rescaled narratives: a case of opposition to mining in Tambogrande, Peru', Political Geography, 26: 289-308.

Hanks, W. (1996) Language and Communciative Practices. oxford: Westview Press.

Harvey, D. (1990) The condition of Post-Modernity. An Enquiry into the Origins of Cultural Change. Oxford: Blackwell.

Haviland, J. (2003) 'Ideologies of language: some reflections on language and U.S. Law', American Anthropologist, 105(4): 764-74.

Heller, M. (2003) Crosswords. Language, Education and Ethnicity in French Ontario. Berlin: Mouton.

Holliday, A. (2005) The Struggle to Teach English as an International Language. Oxford: Oxford University Press.

House, J. (2008) 'Towards a linguistic theory of translation as re-contextualization and a Third Space phenomenon', Linguistica Antverpiensia, 7: 149-75.

Howarth, D. (2000) Discourse. Buckingham: Open University Press.

Irvine, J. T. and Gal, 5. (2000) 'Language ideology and linguistic differentiation', in P. Kroskrity (ed.), Regimes of Language. Santa Fe, NM: School of American Research Press. pp. 35-83.

Jaspers, J. (2005) 'Linguistic sabotage in a context of monolingualism and standardization', Language and Communication, 25: 279-97.

Kaufman, S. (2003) 'What motivates changes that occur in pidgins and creoles', Journal of Pidgin and Creole Languages, 18(1): 107-20.

Kirkpatrick, A. (2007) World Englishes: Implications for International Communication and English Language Teaching. Cambridge: Cambridge University Press.

Krzyźanowski, M. and Wodak, R. (2007) 'Multilingual European institutions and the discourse of EU enlargement in the national public spheres', a pilot study. Lancaster: Department of Linquistics and English Language, Lancaster University. Available at http://www.lancs.ac.uk/fass/doc library/linguistics/wodakr/DYLANWP2Lancasterfinal.pdf.

Kymlicka, W. (1995) Multicultural Citizenship: A Liberal Theory of Minority Rights. Oxford: Oxford University Press.

Kymlikca, W. (2001) Politics in the Vernacular: Nationalism, Multiculturalism and Citizenship. Oxford: Oxford University Press.

Lamont, M. (2000) The Dignity of Working Men. Morality and the Boundaries of Race, Class and Immigration. Harvard: Harvard University Press.

Lash, S., and Urry, R. (1994) Economies of Signs and Space. London: Sage.

Lass, R. (1997) Historical Linguistics. Cambridge: Cambridge University Press.

Lyons, J. (1970) New horizons in Linguistics. Harmondsworth: Penguin.

McConnell, G. (1997) 'Global scale sociolinguistics', in F. Coulmas (ed.), The Handbook of Sociolinguistics. London: Blackwell. pp. 344-57.
Manda, D. S. (2009) Ubuntu philosophy as an African philosophy for peace. Available at http://www.africafiles.org/ article.asp?|D=20359. Accessed 30 March 2009.

Marcus, G. (1998) Ethnography Through Thick and Thin. Princeton, NJ: Princeton University Press.

Maryns, K. (2005) 'Monolingual language ideologies and code choice in the Belgian asylum procedure', Language and Communication, 25: 299-314.

Mazrui, A. (1975) The Political Sociology of the English Language: An African Perspective. The Hague: Mouton and $\mathrm{Co}$.

Moyer, M. (forthcoming) 'Language ideologies and multilingual practices in a health care clinic in Barcelona', Journal of Pragmatics.

Persson, H-A and Stråth, B. (2007) 'Time and space. Introduction to reflections on Europe as a political order', in $\mathrm{H}$. Persson, and B. Stråth (eds), Reflections on Europe. Defining a Political Order in Time and Space, Brussels: Peter Lang. pp. 11-34.

Phillipson, R. (1992) Linguistic Imperialism. Oxford: Oxford University Press.

Preston, P. (2008) Making the News. Journalism and News Cultures in Europe. London: Routledge.

Rampton, B. (1995) Crossing. Language and Ethnicity Among Adolescents. London: Longman.

Rampton, B. (2009) 'Speech community and beyond', in N. Coupland, and A. Jaworski (eds), The New Sociol inguistics Readers. Houndmills: Palgrave Macmillan. pp. 694-713.

Richardson, K. and Meinhof, U. (1999) Worlds in Common? Television Discourse in a Changing Europe. London: Routledge.

Robertson, R. (1990) 'Mapping the global conditions: globalization as the central concept', Theory, Culture and Society, $7(2,3): 15-30$.

Rubdy, R. and Saraceni, M. (2006) English in the World: Global Rules, Global Roles. London: Continuum.

Sassen, 5. (1999) Guests and Aliens. New York: The New Press.

Saville-Troike, M. (2003) The Ethnography of Communication: An Introduction. (3 ed.) Oxford: Blackwell.

Scollon, R. (1997) 'Handbills, tissues, and condoms: a site of engagement for the construction of identity in public discourse', Journal of Sociolinguistics, 1(1): 39-61.

Silverstein, M. (2003) 'Indexical order and the dialectics of sociolinguistic life', Language and Communication, 23(3, 4): 193-229.

Slembrouck, 5. (1998) "'Você decide": formatting the commodified nation', ALW Cahiers, 11: 11-21.

Street B. (1993) Social literacies: Critical Approaches to Literacy in Development, Ethnography and Education. London: Longman.

Swyngedouw, E. (1996) 'Reconstructing citizenship, the re-scaling of the State and the New Authoritarianism: closing the Belgian mines', Urban Studies, 33: $1499-521$.

Taura, H. (2008) Language Attrition and Retention in Japanese Return Students. Sotokanda: Akashi Shoten. 
Thomas, W. and Znaniecki, F. (1918) The Polish Peasant in Europe and America. New York: Alfred Knopf.

Thomason, S. and Kaufman, T. (1988) Language Contact, Creolization and Genetic Linguistics. Berkeley, CA: University of California Press.

Triandafyllidou, A., Wodak, R. and Krzyźanowski, M. (2009) The European Public Sphere and the Media. London: Palgrave Macmillan.

Trinch, 5. (2003) Latinas' Narratives of Domestic Abuse. Discrepant Versions of Violence. Amsterdam: John Benjamins.

Valentine, G., Sporton, D. and Bang Nielsen, K. (2009) 'The spaces of language: the everyday practices of young Somali refugees and asylum seekers', in J. Collins, S. Slembrouck, and M. Baynham (eds), Globalization and Languages in Contact: Scale, Migration, and Communicative Practices. London: Continuum. pp. 189-206.

Vigouroux, C. and Mufwene, S. (eds) (2008) Globalization and Language Vitality, London: Continuum.

Wallerstein, I. (2004) World-Systems Analysis: An Introduction. Durham, NC: Duke University Press.

Zentella, A. (1990) 'Returned migration, language, and identity. Puerto Rico bilinguals in two worlds/dos mundos', in N. Gutmann, F. Rodríguez, L. Stephen and P. Zavella (eds)، Perspectives on Las Américas: A Reader in Culture, History, and Representation. Malden, MA: Wiley-Blackwell. pp. 245-58.

\subsection{INTRC}

Charles San American ph cian. To soci for his theory and nature, Saussure's se and conventi iconic and in objects, theor and context-r tial relations foregroundin over deducti over code. $\mathrm{H}$ understandin which has $\mathrm{F}$ decades of li analysis: for on cohesion, pronouns, an (1990) on si George Hert the relation ated by the which groun biosemiosis Sebeok, 19? Schegloff al (Goffman, 1 act theory (f

This chap ics and prag alize the re statuses and 